\title{
Nasopharyngeal Cancer Clinical Distant Metastasis TNM Finding v8
}

National Cancer Institute

\section{Source}

National Cancer Institute. Nasopharyngeal Cancer Clinical Distant Metastasis TNM

Finding v8. NCI Thesaurus. Code C132811.

A clinical finding about one or more characteristics of nasopharyngeal cancer, following the rules of the TNM AJCC V8 classification system as they pertain to distant metastases. 